\title{
Pengaruh Pendidikan, Pengangguran, dan Kemiskinan terhadap Ketimpangan Pendapatan di Indonesia
}

\author{
Hindun* \\ Pascasarjana Universitas Negeri Surabaya, Indonesia \\ Ady Soejoto \\ Pascasarjana Universitas Negeri Surabaya, Indonesia \\ Hariyati \\ Pascasarjana Universitas Negeri Surabaya, Indonesia
}

\begin{abstract}
This research aims to analyze the effect of education, unemployment, and poverty on income inequality in Indonesia, both partially and simultaneously. This research uses secondary data with a quantitative approach. The type of research used is the type of associative research. The variables in this study are education, unemployment, poverty, and income inequality — data source from BPS and the Ministry of Education and Culture. The data analysis technique used is panel data regression analysis with cross-section 34 provinces and time series for 2015-2018. The results of the research obtained the random effect model, the best models. The results of data analysis show that education and poverty had a partial effect on income inequality in Indonesia, while unemployment had not to affect income inequality. Simultaneously, education, unemployment, and poverty affect income inequality in Indonesia. However, education, unemployment, and poverty can only explain $22.37 \%$ of the effect on income inequality in Indonesia. The rest is influenced by factors outside the model.
\end{abstract}

JEL: I24, J64, O15

Keywords: education, unemployment, poverty, income inequality.

\section{PENDAHULUAN}

Indonesia yang merupakan salah satu negara berkembang yang belum mampu mencapai kestabilan ekonomi. Salah satunya terlihat dari distribusi pendapatan masyarakat yang tidak merata. Jika bagian yang sama dari hasil produksi perekonomian diperoleh setiap orang maka pendapatan didistribusikan secara merata sempurna (Rahardja \& Manurung, 2008). Distribusi pendapatan yang adil, jika semua lapisan masyarakat dapat menikmati hasil produksi nasional, sehingga masyarakat menjadi lebih sejahtera. Kesejahteraan masyarakat dapat ditentukan oleh salah satu faktor penting yaitu ketimpangan pendapatan yang rendah, namun faktor ini sering tidak diperhitungkan dalam membandingkan tingkat kesejahteraan masyarakat dan perubahannya

\footnotetext{
*Email : albangkalani@gmail.com ; hindun.17070925415@mhs.unesa.ac.id Received : 09-08-2019, Accepted: 12-09-2019, Published: 19-12-2019

P-ISSN : 2087-9954, E-ISSN : 2550-0066. DOI : http://dx.doi.org/10.26418/jebik.v8i3.34721
} 
dari waktu ke waktu. Pada umumnya yang dijadikan tolok ukur kesejahteraan masyarakat adalah pendapatan nasional dan pendapatan per kapita (Arsyad, 2017).

Bandyopadhyay (2017) mengungkapkan bahwa indeks gini secara luas telah digunakan sebagai ukuran ketimpangan untuk mengukur tren ketimpangan. Banerjee (2010) juga mengungkapkan hal yang sama bahwa indeks gini merupakan yang paling banyak digunakan dalam mengukur ketimpangan pendapatan dan dapat diperluas ke konteks multidimensi dari pengukuran kesejahteraan dan ketimpangan distribusi kesejahteraan di antara individu dalam sebuah masyarakat seperti pendidikan, kesehatan, dan lain-lain. Gambar 1 menggambarkan data gini rasio di Indonesia sebagai indikator dari ketimpangan (pemerataan) pendapatan yang menunjukkan bahwa masyarakat Indonesia belum sejahtera. Pada tahun 2011-2014, perkembangan gini rasio cenderung fluktuatif. Pada tahun 2014 gini rasio sebesar 0,414, data ini menunjukkan gini rasio tertinggi selama tahun2011-2018. Kondisi ini mengakibatkan ketimpangan pendapatan semakin tinggi. Namun, pada penurunan ini tidak lepas dari peran pemerintah dalam pemerataan pembangunan di seluruh wilayah Indonesia. Namun, nilai gini rasio tahun 2018 masih di atas 0,35. Arsyad (2017) mengungkapkan bahwa indeks gini dari negara-negara yang mendapati ketimpangan rendah berada diantara 0,20-0,35. Negara dengan ketimpangan pendapatan yang rendah, jika nilai koefisien gini-nya mendekati angka 0 . Sebaliknya, jika nilai koefisien gini-nya mendekati angka 1, maka distribusi pendapatannya sangat timpang. Dengan kata lain, nilai koefisien gini berada pada angka 0-1. Dari penjelasan tersebut dapat dikatakan bahwa distribusi pendapatan di Indonesia masih terdapat ketimpangan yang cukup tinggi, sehingga diperlukan perbaikan.

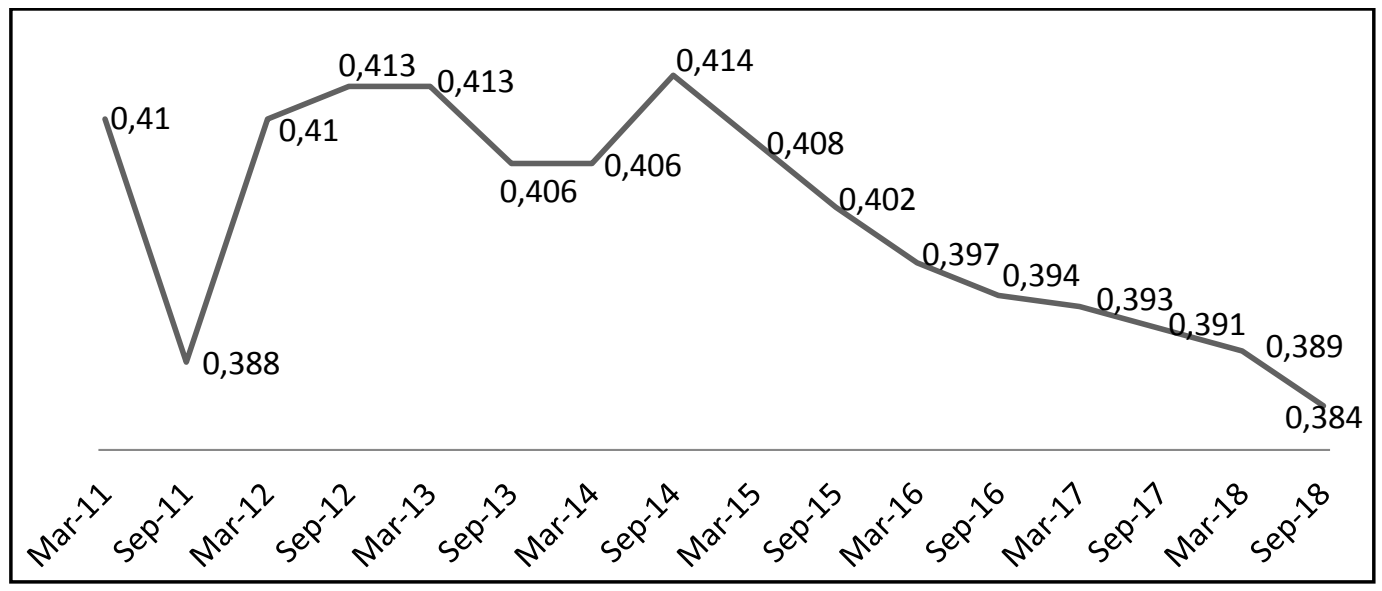

Sumber: BPS 2019, diolah.

\section{Gambar 1. Perkembagan Gini Rasio di Indonesia Maret 2011-September 2018}

Ketimpangan pendapatan yang terjadi dapat disebabkan oleh beberapa faktor. Ada banyak faktor yang berkontribusi pada pertumbuhan ketimpangan distribusi pendapatan, dari disparitas upah, hingga globalisasi (Petcu, 2014). Menurut Dartanto \& Putra (2018) salah satu penyebab utama dari ketimpangan pendapatan/pengeluaran adalah ketimpangan kesempatan, seperti pendidikan dapat mempengaruhi ketimpangan pendapatan dalam jangka panjang.

Menurut Yang \& Qiu (2016) kemampuan bawaan dan investasi keluarga dalam pendidikan awal memainkan peran penting dalam menjelaskan ketimpangan pendapatan dan mobilitas pendapatan antar generasi. Pendidikan yang tinggi dapat terbentuk pada berapa lama mereka menempuh pendidikan atau pada tingkatan pendidikan tinggi, sedangkan mereka yang 
tidak mengenal pendidikan akan jauh dari kualitas yang tinggi sebagai manusia. Oleh sebab itu, perlu adanya peningkatan pendidikan di masyarakat. Pencapaian pendidikan yang tinggi memungkinkan untuk memperoleh pekerjaan lebih mudah, sehingga dapat meningkatkan pendapatan. Pendapatan yang lebih tinggi memungkinkan orang memiliki kehidupan yang lebih baik dan ketimpangan pendapatan semakin rendah.

Tabel 1 menunjukkan salah satu indikator pendidikan tahun 2017/2018, yaitu angka kelulusan tingkat pendidikan formal, baik tingkat SD, SMP, maupun SMA. Pada tingkat SD angka kelulusan tertinggi dimiliki oleh wilayah Jawa, yaitu 99,91\%, sedangkan angka kelulusan terendah dimiliki oleh wilayah Papua, yaitu 98,87\%. Pada tingkat SMP, angka kelulusan tertinggi dimiliki oleh wilayah Kalimantan, yaitu 99,21\%., sedangkan angka kelulusan terendah masih dimiliki oleh wilayah Papua, yaitu 97,38\%. Pada tingkat SMA, angka kelulusan tertinggi sama seperti tingkat SMP dimiliki wilayah Kalimantan, yaitu 99,08\%, sedangkan angka kelulusan terendah dimiliki oleh wilayah Papua, yaitu 98,09\%.

Tabel 1. Angka Kelulusan Tingkat Pendidikan Tiap Wilayah Tahun 2017/2018

\begin{tabular}{lccc}
\hline \multirow{2}{*}{ Wilayah } & SD & SMP & SMA \\
\cline { 2 - 4 } & \multicolumn{3}{c}{ Persen } \\
\hline Sumatera & 99.73 & 99.17 & 98.88 \\
Jawa & 99.91 & 99.11 & 99.03 \\
Bali \& Nusa Tenggara & 99.85 & 98.98 & 98.69 \\
Kalimantan & 99.74 & 99.21 & 99.08 \\
Sulawesi & 99.57 & 99.02 & 98.92 \\
Maluku & 99.55 & 99.02 & 98.39 \\
Papua & 98.87 & 97.38 & 98.09 \\
\hline
\end{tabular}

Sumber: Kemdikbud 2018, diolah

Tabel 1 menggambarkan secara umum angka kelulusan tertinggi diperoleh wilayah Kalimantan, kecuali di tingkat SD, sedangkan angka kelulusan terendah diperoleh oleh wilayah Papua. Hal ini menunjukkan bahwa kualitas pendidikan di Papua masih rendah. Rendahnya kualitas pendidikan di Papua disebabkan akses menuju sekolah relatif jauh, kekurangan tenaga pendidik khususnya di daerah-daerah pedalaman yang menyebabkan proses pembelajaran tidak dapat berlangsung dengan baik (Yeimo, 2016). Selain pendidikan, tingkat pengangguran dan kemiskinan juga mempunyai peran penting untuk mengurangi ketimpangan pendapatan yang terjadi. Peningkatan pengangguran memiliki dampak yang memberatkan pada ketimpangan pendapatan (Cysne \& Turchick, 2012).

Oleh sebab itu, dengan mengurangi pengangguran, maka ketimpangan pendapatan yang terjadi dapat dikurangi. Pada gambar 2, menggambarkan perbandingan tingkat pengangguran di Indonesia tahun 2018. Hampir seluruh wilayah menunjukkan bahwa tingkat setengah pengangguran lebih tinggi dibandingkan dengan tingkat pengangguran terbuka. Hal ini menunjukkan kabar yang cukup baik, karena mereka yang berada pada tingkat setengah pengangguran adalah mereka yang bekerja tetapi tidak optimal dan memiliki pendapatan, sehingga dapat mengurangi ketimpangan pendapatan yang terjadi. Berbeda dengan tingkat pengangguran terbuka adalah mereka yang tidak memiliki pekerjaan dan pendapatan. Pengangguran terbuka akan menambah jarak pemisah antara penduduk miskin dan kaya, 
sehingga ketimpangan pendapatan semakin melebar. Hal ini seperti yang ditunjukkan dari wilayah Jawa, bahwa tingkat pengangguran terbuka lebih tinggi daripada tingkat setengah pengangguran. Pada gambar 2 juga menunjukkan bahwa tingkat pengangguran terendah dimiliki oleh wilayah Bali yaitu sebesar 1,37\% untuk pengangguran terbuka dan 2,36\% untuk setengah pengangguran. Menurut Kepala Dinas Tenaga kerja dan ESDM Bali, Wiratmini (2018) mengatakan sektor pariwisata yang tumbuh signifikan memberi dampak cukup besar pada rendahnya jumlah pengangguran di Pulau Dewata.

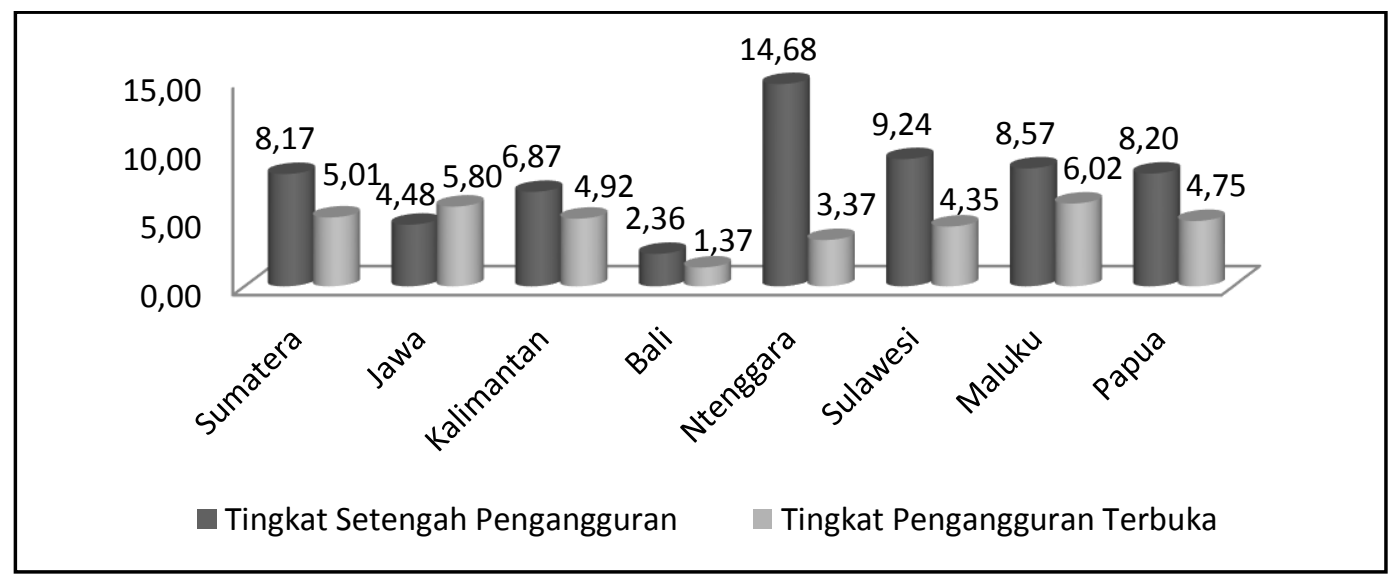

Sumber: BPS 2019, diolah

Gambar 2. Tingkat Setengah Pengangguran Terbuka dan Tingkat Pengangguran Terbuka Menurut Wilayah di Indonesia Tahun 2018 (Persen)

Disamping karena pendidikan dan pengangguran, ketimpangan pendapatan juga dapat disebabkan oleh kemiskinan. Seperti yang diungkapkan oleh Arsyad (2017) mengungkapkan bahwa masalah pemerataan pendapatan juga berkaitan dengan upaya pengentasan kemiskinan. Oleh karena itu, perlu dilakukan upaya untuk mengurangi kemiskinan agar ketimpangan pendapatan yang terjadi semakin rendah.

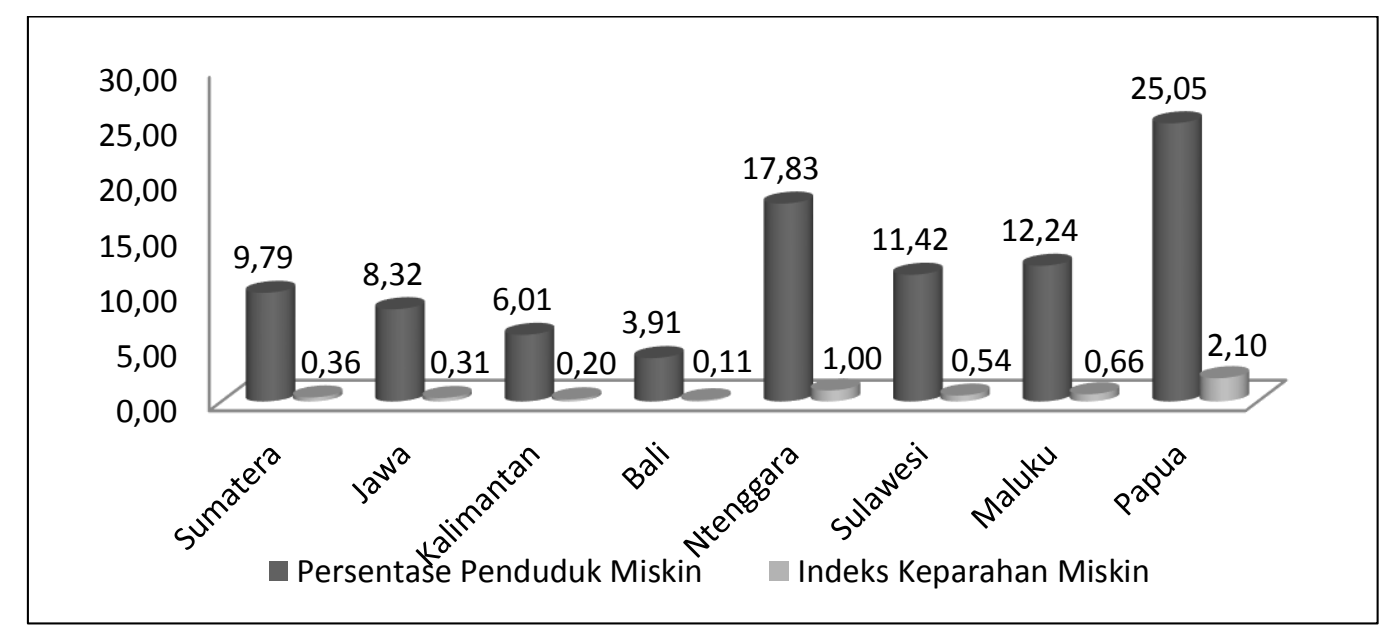

Sumber: BPS 2019, diolah

Gambar 3. Persentase Penduduk Miskin dan Indeks Keparahan Miskin Menurut Wilayah di Indonesia Tahun 2018 (Persen) 
Pada gambar 3 menggambarkan tingkat kemiskinan menurut wilayah di Indonesia tahun 2018. Tingginya tingkat kemiskinan yang terjadi di Indonesia disebabkan oleh kemiskinan yang terjadi di wilayah timur. Tingkat kemiskinan tertinggi dimiliki oleh Papua dan Nusa Tenggara baik dari persentase penduduk miskin maupun indeks keparahan kemiskinan. Penyebab kemiskinan tinggi di wilayah tersebut karena akses yang cukup sulit untuk menjangkau wilayah tersebut khususnya daerah pedalaman. Tingkat kemiskinan terendah berada di wilayah Bali baik dari sisi persentase maupun indeks keparahan kemiskinan yaitu sebesar 3,91\% dan 0,11. Hal ini dikarenakan wilayah ini adalah salah satu pusat dari kegiatan ekonomi, yaitu pusat wisata terbaik di Indonesia sehingga mampu mengurangi kemiskinan.

Berdasarkan penjelasan diatas, ketimpangan pendapatan dapat dikurangi melalui pendidikan, pengangguran dan kemiskinan. Selain dari data pendukung, penelitian terkait juga memberikan kontribusi terhadap pengurangan ketimpangan pendapatan. Penelitian tersebut antara lain: Wahyuni \& Monika (2016) dan (Gregorio, 2002) menyatakan bahwa pembagian pendapatan yang merata di pengaruhi oleh peran penting dari pencapaian pendidikan yang lebih tinggi dan penyaluran pendidikan yang seimbang. Berbeda dengan penelitian Fithrian, Syechalad, \& Nasir (2015) yang menemukan bahwa tingkat pendidikan berpengaruh positif, namun tidak signifikan. Dengan kata lain, pendidikan tidak berpengaruh terhadap ketimpangan pendapatan di Aceh. Hal ini dikarenakan kualitas mutu pendidikan di Aceh masih rendah, meskipun alokasi anggaran yang disediakan pemerintah relatif besar.

Deyshappriya (2017) dan Syilviarani (2017), menurutnya ketimpangan pendapatan dipengaruhi secara signifikan dan positif oleh pengangguran. Jika angka pengangguran bertambah, dampaknya akan mengurangi tingkat upah. Berbeda dengan penemuan Nielson \& Alderson (2015) yang menyatakan peningkatan ketimpangan baru-baru ini memiliki efek ambigu dari pengangguran di Amerika Serikat pada tahun 1970, 1980, dan 1990. Efek dari tingkat pengangguran tidak signifikan pada tahun 1970, tetapi pada tahun 1980 itu adalah negatif dan sangat signifikan, menunjukkan bahwa pengangguran mengurangi ketimpangan pendapatan, bertentangan dengan prediksi. Namun pada tahun 1990, efek pengangguran tidak lagi signifikan.

Apergis, Dincer, \& Payne (2011) menyatakan bahwa dalam jangka pendek pengangguran berdampak positif dan signifikan terhadap ketimpangan pendapatan, sedangkan kemiskinan berdampak positif dan signifikan terhadap ketimpangan pendapatan dalam jangka pendek dan jangka panjang. Begitu juga dengan penelitian dari Hassan, Zaman, \& Gul (2015) menyatakan bahwa dalam jangka panjang terdapat hubungan positif antara kemiskinan dan ketimpangan pendapatan. Berbeda dengan penemuan Andiny \& Mandasari (2017) menyatakan bahwa variabel kemiskinan tidak mempengaruhi variabel ketimpangan di Provinsi Aceh. Ketimpangan di Provinsi Aceh lebih di pengaruhi oleh faktor-faktor lain yang tidak dimasukkan dalam penelitiannya.

Berdasarkan uraian di atas, maka ada beberapa alasan yang mendasari penelitian ini. Pertama, masalah ketimpangan pendapatan di Indonesia belum terselesaikan, yaitu terlihat nilai rasio gini lebih dari 0,35 . Kedua, faktor pendidikan, pengangguran, dan kemiskinan mampu mengurangi ketimpangan pendapatan. Ketiga, ingin membuktikan teori dengan realita di Indonesia. Keempat, membuktikan ada tidaknya pengaruh dari perbedaan hasil penelitian terdahulu. Dari masalah tersebut, peneliti mengangkat tema penelitian terkait ketimpangan 
pendapatan di Indonesia dengan judul "Pengaruh Pendidikan, Pengangguran, dan Kemiskinan terhadap Ketimpangan Pendapatan di Indonesia".

\section{KAJIAN LITERATUR}

\subsection{Pengaruh Pendidikan terhadap Ketimpangan Pendapatan}

Pendidikan merupakan jembatan penghubung untuk segala permasalahan negara. Adanya keterbatasan dalam hal pendidikan akan menyebabkan terhambatnya kesempatan untuk memperoleh pendapatan yang lebih tinggi (Sanz, Peris, \& Escámez, 2017). Oleh karena itu, pemerintah selalu berupaya berinvestasi di bidang pendidikan. Hal ini terbukti dari pengeluaran pemerintah untuk pendidikan setidaknya 20\% dari APBN. Hal inilah, pendidikan telah menjadi kebutuhan pokok bagi seluruh lapisan masyarakat (Bintang \& Woyanti, 2018).

Danim (2004) juga mengemukakan bahwa ada tiga alasan investasi di bidang pendidikan. Pertama, pendidikan dapat meningkatkan produktivitas pendapatan di bidang pertanian dan membantu menyerap tenaga kerja ke dalam industri modern. Kedua, investasi pendidikan dapat membantu mengurangi kesenjangan pendapatan. Ketiga, distribusi kesempatan pendidikan bisa digunakan sebagai alat redistribusi pendapatan. Uraian di atas menjelaskan bahwa pendidikan erat sekali hubungannya dengan ketimpangan pendapatan. Dengan pendidikan, permasalahan suatu negara akan berkurang seperti yang dikemukakan oleh beberapa peneliti terkait hubungan pengaruh pendidikan terhadap ketimpangan pendapatan sebagai berikut:

Shahpari \& Davoudi (2013) mengungkapkan bahwa penambahan modal manusia (tingkat rata-rata sekolah tenaga kerja) dapat membuat distribusi pendapatan merata dalam jangka panjang. Kemudian, Meisami (2010) menyatakan bahwa status pendidikan dalam Negaranegara Islam akan mengurangi ketimpangan pendapatan. Berdasarkan beberapa hasil penelitian diatas, apabila pendidikan meningkat, maka akan mengurangi ketimpangan distribusi pendapatan. Hal tersebut dapat dijelaskan bahwa seseorang yang memiliki pendidikan tinggi, umumnya akan memperoleh pendapatan yang tinggi dibanding dengan mereka yang berpendidikan rendah. Jarak kesenjangan pendapatan antar orang dapat dikurangi dengan pendapatan yang tinggi. Jika hal ini terjadi hampir diseluruh lapisan masyarakat, maka distribusi pendapatan akan semakin merata dan koefisien gini mendekati angka nol. Jadi, dapat disimpulkan bahwa pendidikan berpengaruh signifikan dan berpengaruh negatif terhadap ketimpangan pendapatan.

\subsection{Pengaruh Pengangguran terhadap Ketimpangan Pendapatan}

Mankiw, Quah, \& Wilson (2014) mendefinisikan pengangguran adalah seseorang yang berhenti bekerja sementara atau sedang mencari pekerjaan. Seseorang yang menganggur tidak memperoleh pendapatan. Semakin besar pengangguran, semakin banyak golongan tenaga kerja yang tidak mempunyai pendapatan. Pengangguran yang terlalu besar dapat menurunkan upah golongan berpendapatan rendah sehingga ketimpangan pendapatan semakin tinggi (Sukirno, 2011). Situasi seperti ini yang mengharuskan bahwa lowongan kerja harus disediakan dan harus diciptakan sesuai dengan perubahan jumlah tenaga kerja, agar pembagian pendapatan menjadi merata. 
Memperkuat penjelasan di atas, berikut beberapa penelitian terkait pengaruh pengangguran terhadap ketimpangan pendapatan. Dalam penelitian Ukpere \& Slabbert (2009), pengangguran menambah tingkat ketimpangan diantara masyarakat. Pi \& Zhang (2018) mengungkapkan bahwa pengangguran sektoral di sektor terampil perkotaan mengakibatkan ketimpangan upah menjadi lebih luas, jika rasio modal tenaga kerja di sektor ini lebih dari satu. Efriza (2014) juga mengungkapkan bahwa terdapat pengaruh positif antara tingkat pengangguran dan ketimpangan pendapatan. Kemudian, temuan Cysne \& Turchick (2012) yang menenukan bahwa terdapat hubungan positif antara pengangguran dan ketimpangan pendapatan. Berdasarkan uraian di atas, apabila pengangguran semakin meningkat, maka ketimpangan pendapatan semakin meningkat. Jadi, dapat disimpulkan bahwa pengangguran dapat berpengaruh terhadap ketimpangan pendapatan. Hubungan antara pengangguran dan ketimpangan pendapatan adalah positif.

\subsection{Pengaruh Kemiskinan terhadap Ketimpangan Pendapatan}

Ketimpangan pendapatan sangat erat hubungannya dengan kemiskinan relatif (Badrudin, 2017). Kemiskinan menyebabkan ketimpangan distribusi pendapatan antara kaya dan miskin semakin timpang. Seperti yang ungkapkan oleh Arsyad (2017) tidak tercapainya pengurangan yang berarti pada angka kemiskinan mengakibatkan ketimpangan dalam distribusi pendapatan di Negara berkembang semakin meningkat. Oleh sebab itu, penurunan kemiskinan sangat diperlukan, agar ketimpangan pendapatan di masyarakat semakin rendah.

Adapun beberapa penelitian terkait hubungan pengaruh kemiskinan terhadap ketimpangan pendapatan sebagai berikut. Dalam penelitiannya, Hassan et al. (2015) menyatakan bahwa dalam jangka panjang terdapat hubungan positif antara kemiskinan dan ketimpangan pendapatan. Syawie (2011) mengungkapkan bahwa pada proporsi tertentu, kemiskinan memang berkaitan dengan kesenjangan. Akan tetapi, kemiskinan yang berkurang bukan berarti akan mengurangi ketimpangan. Penemuan Syawie juga didukung oleh Afandy, Rantung, \& Marashdeh (2017) yang menyatakan bahwa angka kemiskinan yang semakin rendah justru menaikkan ketimpangan, sehingga solusi atau langkah-langkah untuk mengurangi kemiskinan dapat bersifat memihak pada ketimpangan, melainkan dibiarkan ketimpangan semakin naik.

Berdasarkan penelitian tersebut dapat disimpulkan bahwa terdapat beberapa penafsiran terkait hubungan antara kemiskinan dan ketimpangan pendapatan. Temuan tersebut ada yang berhubungan positif, dan juga berhubungan negatif. Pada penelitian ini diharapkan, tingkat kemiskinan mempunyai pengaruh positif dan signifikan terhadap ketimpangan pendapatan.

\subsection{Pengaruh Pendidikan, Pengangguran dan Kemiskinan terhadap Ketimpangan Pendapatan}

Distribusi pendapatan mempunyai hubungan yang sangat erat dengan pembangunan ekonomi. Oleh karena itu, adanya hubungan timbal balik yang tidak dapat dipisahkan di antara keduanya. Distribusi pendapatan yang timpang dapat memperburuk pembangunan ekonomi jika perencanaan pendapatan tidak tepat dan menyeluruh. Arsyad (2017) mengungkapkan ada keterkaitan yang erat antara besarnya tingkat pengangguran, besarnya kemiskinan, dan pembagian pendapatan yang timpang. Deyshappriya (2017) mengungkapkan pendidikan dapat mengurangi ketimpangan pendapatan, sedangkan pengangguran dapat meningkatkan ketimpangan pendapatan. Penelitian Afandy et al. (2017) juga menghasilkan bahwa pendidikan (partisipasi kuliah) dan kemiskinan berpengaruh 
terhadap ketimpangan pendapatan. Jadi, dapat disimpulkan bahwa pendidikan, pengangguran, dan kemiskinan mempengaruhi ketimpangan pendapatan.

\subsection{Hipotesis dan Model Penelitian}

Hipotesis adalah jawaban sementara terhadap masalah penelitian hingga terbuktinya melalui pengolahan data yang terkumpul. Berdasarkan teori dan kajian pustaka, serta penelitian terkait yang terdahulu, maka dalam penelitian ini hipotesis yang digunakan adalah sebagai berikut.

H1: Diduga pendidikan berpengaruh terhadap ketimpangan pendapatan di Indonesia.

$\mathrm{H} 2$ : Diduga pengangguran berpengaruh terhadap ketimpangan pendapatan di Indonesia.

H3: Diduga kemiskinan berpengaruh terhadap ketimpangan pendapatan di Indonesia.

H4: Diduga pendidikan, pengangguran, dan kemiskinan berpengaruh secara simultan terhadap ketimpangan pendapatan di Indonesia.

Untuk mempermudah penelitian ini, maka dilakukan suatu rancangan model penelitian hubungan antara variabel bebas dan variabel terikat. Gambar 4. menggambarkan desain model penelitian dalam penelitian ini, diharapkan variabel pendidikan, pengangguran, dan kemiskinan akan mempengaruhi variabel ketimpangan distribusi pendapatan. Ketiga variabel bebas tersebut baik secara parsial maupun simultan akan mempengaruhi variabel ketimpangan pendapatan dengan e adalah standar kesalahan dalam estimasi. Berikut ini adalah desain model penelitian yang akan digunakan dalam penelitian ini.

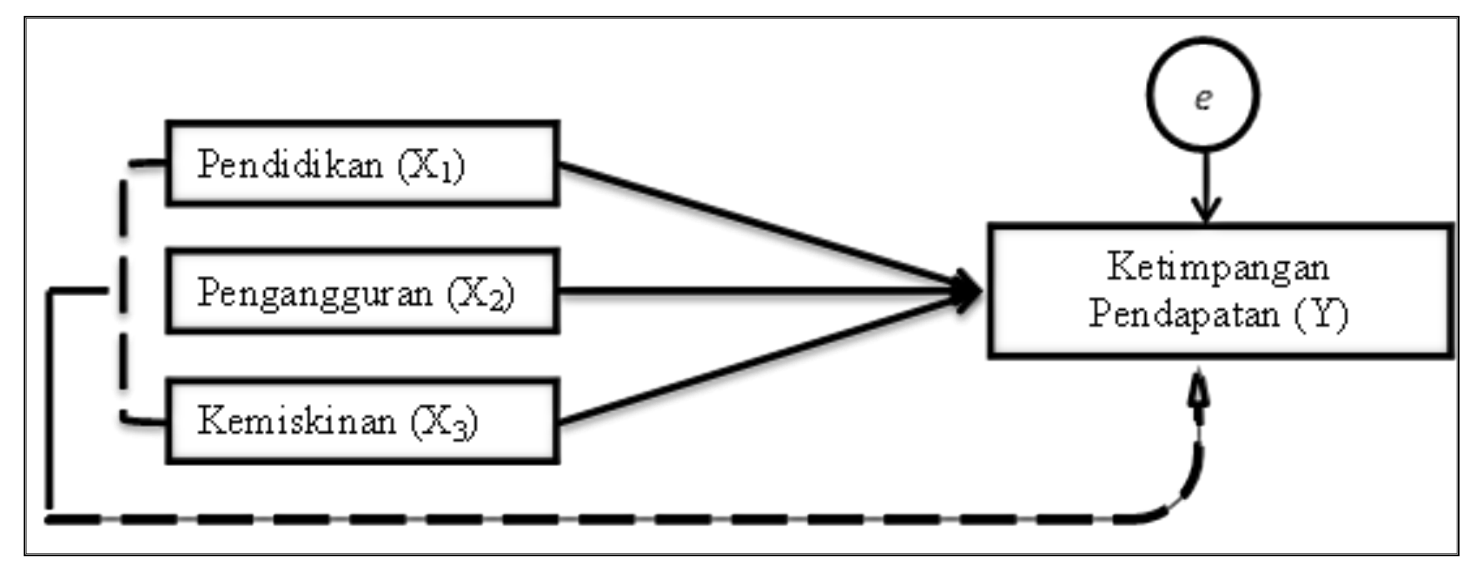

Keterangan:

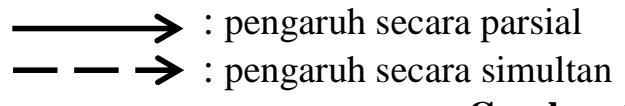

Gambar 4. Model Penelitian

\section{METODE PENELITIAN}

Penelitian ini menggunakan jenis data sekunder dengan pendekatan kuantitatif. Jenis penelitian yang digunakan adalah jenis penelitian asosiatif. Data yang digunakan diperoleh dari BPS dan Kemdikbud. Variabel dalam penelitian ini adalah pendidikan, pengangguran, kemiskinan, dan ketimpangan pendapatan. Pendidikan diukur menggunakan jumlah penduduk 
yang ditamatkan pada pendidikan formal tingkat SMA tahun 2015-2018 yang diperoleh dari Kemendikbud, sedangkan variable yang lain diperoleh dari BPS. Pengangguran diukur menggunakan jumlah pengangguran terbuka tahun 2015-2018. Kemiskinan diukur menggunakan jumlah penduduk miskin tahun 2015-2018. Ketimpangan pengeluaran penduduk yang diukur berdasarkan gini rasio tahun 2015-2018.

Populasi dalam penelitian ini terdiri dari data cross section 34 provinsi dan data time series sebanyak 4 tahun, yaitu tahun 2015-2018. Pengambilan sampel dalam penelitian ini dilakukan secara menyeluruh atau menggunakan sampel jenuh, artinya metode pemilihan sampel dipilih secara menyeluruh atau semua anggota populasi digunakan sebagai sampel.

Penelitian ini menggunakan teknik analisis regresi data panel. Regresi data panel adalah suatu alat analisis data dengan menggabungkan dua jenis data, yaitu data time series dan data cross section. Menurut Ghozali (2016) menggunakan data panel dapat memberikan data yang lebih informatif, lebih bervariasi, rendah tingkat kolonieritas antar variabel, lebih besar degree of freedom dan lebih efisien. Model regresi linier memiliki kelemahan dalam interpretasi koefisien yang akan menimbulkan kesalahan dalam analisis. Oleh sebab itu, model regresi linier dapat ditutupi dengan mentransformasi model ke dalam model log-log, log-lin, atau lin-log. Model persamaan tersebut diharapkan mampu menutupi beberapa kelemahan regresi linier (Nachrowi \& Usman, 2006). Dengan memasukkan variabel-variabel penelitian ini dan model lin-log ke dalam persamaan atau formula data panel, maka formula tersebut dapat ditulis sebagai berikut.

Gini $=\beta 0+\beta 1$ Leduit $+\beta 2$ Lunempit $+\beta 3$ Lpovit + eit

Dimana Gini it merupakan ketimpangan pendapatan menurut provinsi i pada tahun $t$ (ketimpangan pendapatan), Ledu ${ }_{i t}$ adalah logaritma pendidikan menurut provinsi i pada tahun $t$ (pendidikan), Lunempit adalah logaritma pengangguran menurut provinsi $\mathrm{i}$ pada tahun $\mathrm{t}$ (pengangguran), dan $\operatorname{Lpov}_{i t}$ adalah logaritma kemiskinan menurut provinsi $\mathrm{i}$ pada tahun $\mathrm{t}$ (kemiskinan).

Dalam menggunakan data panel, terdapat tiga metode yang dapat dipakai untuk mengestimasi model regresi dengan data panel, yaitu Pendekatan Pooled Least Square (PLS) atau Common Effect, Pendekatan Fixed Effect (FE) atau Model Efek Tetap (MET), dan Pendekatan efek acak (random effect) atau Model Efek Random (MER). Untuk menentukan model regresi terbaik, maka dilakukan pemilihan data. Widarjono (2007) menyatakan bahwa pemilihan teknik estimasi regresi data panel terdapat tiga pengujian, yaitu uji $\mathrm{F}$ statistik, uji hausman, dan uji lagrange multiplier (LM).

Uji F statistik digunakan untuk memilih model apa yang terbaik antara model PLS dan FE. Jika probabilitas F lebih kecil dari $\alpha(0.05)$, maka model yang tepat digunakan adalah model FE. Sebaliknya, Jika probabilitas F lebih besar dari $\alpha$ maka model yang tepat digunakan adalah model PLS. Uji hausman digunakan untuk memilih model apa yang terbaik antara model fixed effect dan random effect. Jika pada pengujian menunjukkan hasil signifikan (Prob. Chi-Square < $\alpha$ ), artinya yang dipilih adalah fixed effect. Sebaliknya, jika tidak signifikan (Prob. Chi-Square > $\alpha$ ), maka model yang terbaik adalah random effect. Jika model yang tepat pada uji hausman adalah model RE, maka dilakukan uji pemilihan yang ketiga, yaitu uji LM. Jika model yang tepat adalah model FE, maka dilanjutkan pada interpretasi model regresi, yaitu uji hipotesis dan koefisien determinasi. 
Uji lagrange multiplier digunakan untuk memilih antara model pooled least square dan random effect. Jika tidak signifikan (Prob. Chi-Square $>\alpha$ ), maka metode estimasi yang terbaik adalah PLS. sebaliknya, jika pada pengujian menunjukkan hasil signifikan (Prob. Chi-Square < $\alpha$ ), berarti metode yang dipilih adalah random effect. Setelah diperoleh model yang terbaik, dilanjutkan pada pengujian hipotesis, yaitu uji simultan (uji F) dan uji parsial (uji t). Jika signifikansi $\mathrm{t}$ atau $\mathrm{F}<0,05$, maka variabel pendidikan, pengangguran, dan kemiskinan berpengaruh terhadap ketimpangan pendapatan secara simultan atau parsial. Selain uji hipotesis, model regresi baik atau tidak dapat dilihat dari koefisien determinasi. Semakin mendekati angka 1 , semakin baik model regresi, karena dapat menjelaskan pengaruh variable bebas terhadap varibel terikat.

\section{HASIL PENELITIAN DAN PEMBAHASAN}

Berdasarkan hasil pengolahan data pada program Stata9, maka diperoleh hasil pemilihan teknik estimasi regresi data panel sebagai berikut:

1. Uji F/Common effect

Tabel 2. Hasil Uji F Statistik

\begin{tabular}{llll}
\hline F test that all $u \_i=0:$ & $F(33,99)=22.93$ & Prob $>F=0.0000$ \\
\hline
\end{tabular}

Dari hasil uji F statistik pada tabel 2. dapat dilihat nilai Prob $>\mathrm{F}$ adalah sebesar 0.0000 . Hal ini menunjukkan bahwa Prob $>$ F lebih kecil dari $\alpha$, yaitu $0.0000<0.05$. Oleh sebab itu, $\mathrm{H}_{\mathrm{a}}$ diterima, yaitu model yang tepat digunakan adalah model fixed effect.

2. Uji Hausman

Tabel 3. Hasil Uji Hausman

$\begin{aligned} \mathrm{Chi}^{2}(3) & =(\mathrm{b}-\mathrm{B})^{\prime}\left[\left(\mathrm{V}_{-} \mathrm{b}-\mathrm{V} \_\mathrm{B}\right)^{\wedge}(-1)\right](\mathrm{b}-\mathrm{B}) \\ & =2.41 \\ \text { Prob }>\mathrm{chi}^{2} & =0.4921\end{aligned}$

Dari hasil uji hausman pada tabel 3 dapat dilihat nilai Prob>Chi-Square adalah sebesar 0.4921. Hal ini menunjukkan bahwa Prob> Chi-Square lebih besar dari $\alpha$, yaitu $0.4921>0.05$. Oleh sebab itu, H0 diterima, yaitu model yang tepat digunakan adalah model random effect.

3. Uji Lagrange Multiplier

Hasil pengujian uji hausman menghasilkan model random effect adalah model terbaik. Oleh karena itu, dilanjutkan pada uji pemilihan model yang ketiga, yaitu uji lagrange multiplier. Berikut hasil uji LM.

Tabel 4. Hasil Uji Lagrange Multiplier

\begin{tabular}{r}
\hline Breusch and Pagan Lagrangian Multiplier Test: \\
\hline Chi $^{2}(1)=144.49$ \\
Prob $>$ chi $^{2}=0.0000$
\end{tabular}

Hasil uji lagrange multiplier pada tabel 4 dapat dilihat dari nilai Prob>Chi-Square dengan metode Breusch-Pagan adalah sebesar 0.0000. Hal ini menunjukkan bahwa Prob> Chi-Square lebih kecil dari $\alpha$, yaitu $0.0000<0.05$. Oleh sebab itu, model yang tepat digunakan adalah model random effect. Berdasarkan hasil pemilihan estimasi diperoleh model random effect sebagai model terbaik. Berikut hasil uji t model random effect. 
Tabel 5. Hasil Uji t Metode Random Effect

\begin{tabular}{rrrrrrr}
\hline gini & Coef. & Std. Err. & $\mathrm{z}$ & $\mathrm{P}>|\mathrm{z}|$ & \multicolumn{2}{c}{ [95\% Conf. Interval] } \\
\hline ledu & -0.0211088 & 0.0103114 & -2.05 & 0.041 & -0.0413188 & -0.0008989 \\
lunemp & 0.0012552 & 0.0020025 & 0.63 & 0.531 & -0.0026696 & 0.0051801 \\
lpov & 0.028837 & 0.0090432 & 3.19 & 0.001 & 0.0111127 & 0.0465613 \\
cons & 0.2482997 & 0.0319719 & 7.77 & 0.000 & 0.1856359 & 0.3109636 \\
\hline
\end{tabular}

Hasil uji t metode random effect berdasarkan tabel 5 dapat diperoleh sebagai berikut:

1. Pada variabel pendidikan dapat diperoleh nilai $\mathrm{P}>|\mathrm{z}|<\alpha$, yaitu $0.041<0.05$. Oleh karena itu, Ho ditolak yang artinya variabel ketimpangan pendapatan dipengaruhi secara parsial oleh variabel pendidikan di Indonesia.

2. Pada variabel pengangguran dapat diperoleh nilai $\mathrm{P}>|\mathrm{Z}|>\alpha$, yaitu $0.531>0.05$. Oleh karena itu, Ho diterima yang artinya variabel ketimpangan pendapatan tidak dipengaruhi secara parsial oleh variabel pengangguran di Indonesia.

3. Pada variabel kemiskinan dapat diperoleh nilai $\mathrm{P}>|\mathrm{z}|<\alpha$, yaitu $0.001<0.05$. Oleh karena itu, Ho ditolak yang artinya variabel ketimpangan pendapatan dipengaruhi secara parsial oleh variabel kemiskinan di Indonesia.

Kemudian hasil uji F yang diperoleh dengan metode random effect pada Stata 9 sebagai berikut :

Tabel 6. Hasil Uji F (Wald $\mathrm{Chi}^{2}$ ) Metode Random Effect

\begin{tabular}{llr}
\hline Wald $_{\text {chi }}^{2}$ & $=$ & 13.57 \\
\hline Prob $>$ chi $^{2}$ & $=$ & 0.0036 \\
\hline
\end{tabular}

Hasil uji F metode random effect berdasarkan tabel 6 dapat diperoleh bahwa nilai (Prob $>$ Chi-Square) $<\alpha$, yaitu $0.0036<0.05$. Oleh karena itu, variabel pendidikan, pengangguran, dan kemiskinan secara bersama-sama mempunyai pengaruh terhadap variabel ketimpangan pendapatan di Indonesia. Adapun hasil koefisien determinasi metode random effect adalah sebagai berikut :

\begin{tabular}{llll} 
Tabel 7. Hasil Koefisien & Determinasi \\
\hline R-sq: & within & $=$ & 0.0364 \\
& between & $=$ & 0.2434 \\
& overall & $=$ & 0.2237 \\
\hline
\end{tabular}

Berdasarkan tabel 7 menunjukkan bahwa nilai $\mathrm{R}$ square overall sebesar 0.2237. Hal ini menunjukkan bahwa variabel pendidikan, pengangguran, dan kemiskinan dapat menjelaskan pengaruhnya terhadap ketimpangan pendapatan di Indonesia sebesar $22.37 \%$, sedangkan sisanya $77.63 \%$ dijelaskan oleh faktor lain diluar model regresi.

Selanjutnya, dari hasil estimasi model regresi data panel diperoleh model sebagai berikut:

Gini $=0.2483-0.02111$ ledu $_{\text {it }}+0.00126$ lunemp $_{\text {it }}+0.0288$ lpov $_{\text {it }}+\varepsilon_{\text {it }}$

Berdasarkan dari model persamaan di atas, maka dapat diinterpretasikan seperti sebagai berikut:

1. Nilai konstanta $\left(\beta_{0}\right)$ sebesar 0.2483 , artinya jika variabel pendidikan, pengangguran, dan kemiskinan adalah konstan, maka ketimpangan pendapatan sama dengan konstanta 0.2483

2. Nilai koefisien dari variabel pendidikan $\left(\beta_{1}\right)$ sebesar -0.02111 , artinya jika variabel pendidikan naik sebesar 1, sedangkan faktor variabel lain tetap, maka ketimpangan pendapatan akan turun sebesar 0.02111 . 
3. Nilai koefisien dari variabel pengangguran $\left(\beta_{2}\right)$ sebesar 0.00126 , artinya jika variabel pengangguran naik sebesar 1 , sedangkan faktor lain tetap, maka ketimpangan pendapatan akan naik sebesar 0.00126. Namun, karena nilai prob $\mathrm{t}(\mathrm{P}>|\mathrm{z}|)$ adalah $0.531>0.05$, maka pengangguran tidak berpengaruh terhadap ketimpangan pendapatan. Oleh sebab itu, berapapun besarnya koefisien pengangguran, maka tidak akan berpengaruh terhadap ketimpangan pendapatan.

4. Nilai koefisien dari variabel kemiskinan $\left(\beta_{3}\right)$ sebesar 0.0288 , artinya jika variabel kemiskinan naik sebesar 1, sedangkan faktor lain tetap, maka ketimpangan pendapatan akan naik sebesar 0.0288 .

Berdasarkan hasil analisis pengolahan data, hasil menunjukkan bahwa pendidikan berpengaruh secara signifikan terhadap ketimpangan pendapatan. Hal ini dapat dilihat dari koefisien regresi yang cukup signifikan. Nilai negatif pada variabel ini mendeskripsikan bahwa pendidikan mempunyai pola hubungan berbanding terbalik dengan ketimpangan pendapatan yaitu semakin tinggi pendidikan, maka semakin rendah ketimpangan pendapatan.

Faktor pendidikan sangat penting dalam mempengaruhi ketimpangan pendapatan di Indonesia. Pendidikan yan berkualitas akan menghasilkan sumber daya manusia yang handal dalam jangka panjang. Namun, untuk mewujudkan hal tersebut dibutuhkan pengorbanan dan biaya yang tidak sedikit. Dalam hal inilah, perlunya kesadaran bagi masyarakat Indonesia menyadari bahwa memang pentingnya pendidikan bagi diri sendiri dan bangsa. Apabila masyarakat merubah pola pikir, maka tujuan Negara dalam dalam pembangunan bangsa akan tercapai yaitu ketimpangan pendapatan semakin rendah. Dengan pendidikan yang semakin tinggi akan memberikan dampak pada peningkatan pengetahuan dan keterampilan, sehingga dapat mempengaruhi tingkat pendapatan melalui pekerjaan yang dimilikinya yang selanjutnya akan dapat berdampak pada ketimpangan pendapatan semakin rendah.

Hasil penelitian ini sesuai dengan beberapa penelitian terdahulu, diantaranya penelitian Gregorio (2002), Meisami (2010), Shahpari \& Davoudi (2013), dan Wahyuni \& Monika (2016) yang menyatakan bahwa tingkat pendidikan yang semakin tinggi mempunyai pengaruh terhadap pemerataan pendapatan yang semakin meningkat. Tetapi, hasil penelitian ini ternyata tidak sesuai dengan penelitian Fithrian et al. (2015) yang menemukan bahwa tingkat pendidikan di Aceh tidak berpengaruh. Hal ini dikarenakan kualitas mutu pendidikan di Aceh masih rendah, meskipun alokasi anggaran yang disediakan pemerintah relatif besar.

Kemudian, variabel pengangguran menunjukkan tidak berpengaruh terhadap ketimpangan pendapatan di Indonesia. Artinya berapapun angka pengangguran tidak akan berpengaruh terhadap ketimpangan pendapatan di Indonesia. Tidak berpengaruhnya pengangguran terhadap ketimpangan pendapatan di Indonesia dapat disebabkan karena kebijakan yang dilakukan oleh pemerintah, seperti Bantuan sosial dari pemerintah yaitu berbentuk Program Keluarga Harapan (PKH), Bantuan Pangan Non Tunai (BPNT), Beras Sejahtera (Rastra), Dana Desa, Kartu Indonesia Sehat (KIS) dan Kartu Indonesia Pintar (KIP). Adanya bantuan tersebut dapat meringankan beban masyarakat karena kebutuhan hidup dapat terpenuhi, meskipun masih belum merata di seluruh wilayah Indonesia. Selain itu, kebutuhan hidup pengangguran sebagian besar masih bergantung pada keluarga yang bekerja, dan menggunakan harta/tabungan yang dimiliki hingga memperoleh pekerjaan dan upah. 
Penelitian ini sesuai dengan penelitian Nielson \& Alderson (2015) yang menyatakan bahwa pada tahun 1970 dan 1990, pengangguran tidak mempunyai pengaruh terhadap ketimpangan pendapatan. Tetapi, tidak sesuai dengan beberapa penelitian terdahulu, diantaranya penelitian oleh Cysne \& Turchick (2012), Deyshappriya (2017), Pi \& Zhang (2018), Syilviarani (2017), dan Ukpere \& Slabbert (2009) yang menemukan bahwa pengangguran meningkatkan ketimpangan pendapatan.

Selanjutnya variabel kemiskinan berpengaruh signifikan secara parsial terhadap kemiskinan. Pada hasil pengujian, hubungan kemiskinan terhadap ketimpangan pendapatan adalah positif. Artinya semakin tinggi kemiskinan, maka ketimpangan pendapatan akan semakin tinggi, atau sebaliknya. Kemiskinan merupakan salah satu faktor yang dapat mempengaruhi terjadinya ketimpangan pendapatan. Kemiskinan terjadi karena tidak terpenuhinya kebutuhan minimum. Ketika kemiskinan berkurang, hal ini menunjukkan bahwa masyarakat telah mampu memenuhi kebutuhan minimumnya. Kebutuhan minimum terpenuhi disebabkan pendapatan yang mereka peroleh semakin meningkat. Meningkatnya pendapatan di masyarakat akan memperkecil celah perbedaan pendapatan yang mereka peroleh, sehingga ketimpangan pendapatan turun. Hal ini tidak lepas dari kebijakan yang dilakukan oleh pemerintah untuk mengurangi kemiskinan, seperti memberikan pelatihan kerja gratis dengan harapan dapat berwirausaha, sehingga memperoleh pendapatan yang nantinya dapat memenuhi kebutuhan minimalnya. Pada akhirnya berdampak pada penurunan ketimpangan pendapatan.

Hasil penelitian ini sesuai dengan beberapa penelitian terdahulu, diantaranya penelitian Apergis et al. (2011) yang mengatakan bahwa kemiskinan berdampak positif dan signifikan terhadap ketimpangan pendapatan dalam jangka pendek dan jangka panjang. Kemudian, penelitian Hassan et al. (2015) yang menyatakan bahwa terdapat hubungan positif dan signifikan antara kemiskinan dan ketimpangan pendapatan. Tetapi hasil penelitian ini tidak mendukung penelitian dari Andiny \& Mandasari (2017) yang menyatakan bahwa variabel kemiskinan tidak mempengaruhi variable ketimpangan pendapatan.

Terakhir, hasil analisis regresi data panel menunjukkan bahwa variabel pendidikan, pengangguran, dan kemiskinan secara bersama-sama mempunyai pengaruh terhadap ketimpangan pendapatan di Indonesia. Hal ini menunjukkan bahwa ketika seseorang dapat memenuhi kebutuhan minimal bahkan lebih, ini menunjukkan bahwa pendapatannya semakin tinggi. Pada akhirnya ketimpangan pendapatan semakin rendah. Disisi lain, pendidikan yang berkualitas akan memiliki pengetahuan dan keterampilan yang lebih baik, yang pada akhirnya berdampak pada ketimpangan pendapatan, serta pengangguran yang semakin rendah mengindikasikan penduduk yang bekerja lebih banyak, sehingga mereka memperoleh pendapatan untuk memenuhi kebutuhannya. Pada akhirnya ketimpangan pendapatan semakin rendah.

\section{SIMPULAN}

Berdasarkan hasil penelitian dan pembahasan yang telah diuraikan mengenai hubungan antara pendidikan, pengangguran, dan kemiskinan terhadap ketimpangan pendapatan di Indonesia, baik secara parsial maupun simultan selama tahun 2015-2018, maka dapat disimpulkan bahwa pendidikan dan kemiskinan berpengaruh secara parsial terhadap ketimpangan pendapatan di Indonesia, sedangkan pengangguran tidak berpengaruh. Kemudian, 
pendidikan, pengangguran, dan kemiskinan berpengaruh secara simultan terhadap ketimpangan pendapatan. Penelitian berikutnya diharapkan dapat menggunakan variabel yang berbeda terutama yang belum dimasukkan dalam model penelitian ini seperti pajak, tingkat pendidikan yang lain, dan lain-lain.

\section{DAFTAR PUSTAKA}

Afandy, A., Rantung, V. P., \& Marashdeh, H. (2017). Determinants of Income Inequality. Economic Journal of Emerging Markets, 9(2), 159-171.

Andiny, P., \& Mandasari, P. (2017). Analisis Pertumbuhan Ekonomi dan Kemiskinan Di Indonesia. , 1(2), 196-210. Jurnal Penelitian Ekonomi Akuntansi, 1(2), 196-210.

Apergis, N., Dincer, O., \& Payne, J. E. (2011). On the Dynamics of Poverty and Income. Journal of Economics Studies, 38(2), 132-143.

Arsyad, L. (2017). Ekonomi Pembangunan (5th ed.). Yogyakarta: UPP STIM YKPN.

Badrudin, R. (2017). Ekonomika Otonomi Daerah (2nd ed.). Yogyakarta: UPP STIM YKPN.

Bandyopadhyay, S. (2017). The Absolute Gini Is A More Reliable Measure Of Inequality For Time Dependent Analyses (Compared With The Relative Gini). Economics Letters, 162, $1-15$.

Banerjee, A. K. (2010). A Multidimensional Gini Index. Mathematical Social Sciences, 60(2), 87-93.

Bintang, A. B. M., \& Woyanti, N. (2018). Pengaruh PDRB, Pendidikan, Kesehatan dan Pengangguran terhadap Tingkat Kemiskinan di Jawa Tengah (2011-2015). Media Ekonomi Dan Manajemen, 33(1), 20-28.

Cysne, R. P., \& Turchick, D. (2012). Equilibrium Unemployment-Inequality Correlation. Journal of Macroeconomics, 34(2), 454-469.

Danim, S. (2004). Ekonomi Sumber Daya Manusia. Bandung: CV. Pustaka Setia.

Dartanto, T., \& Putra, N. E. (2018). Ketimpangan Kesempatan Jadi Penyebab Ketimpangan Pendapatan. Retrieved January 28, 2019, from www.feb.ui.ac.id

Deyshappriya, N. P. R. (2017). Impact of Macroeconomic Factors on Income Inequality and Income Distribution in Asian Countries (No. 696). Tokyo: Asian Development Bank Institute.

Efriza, U. (2014). Analisis Kesenjangan Pendapatan Antar Kabupaten/Kota Di Provinsi Jawa Timur Di Era Desentralisasi Fiskal. Jurnal Ilmiah Mahasiswa FEB Universitas Brawijaya, 2(2).

Fithrian, M., Syechalad, N., \& Nasir, M. (2015). Analisis Pengaruh Aggregat Demand dan Tingkat Pendidikan terhadap Ketimpangan Pendapatan di Aceh. Jurnal Ilmu Ekonomi Pascasarjana Universitas Syiah Kuala, 3(3), 23-32.

Ghozali, I. (2016). Aplikasi Analisis Multivariete dengan Program IBM SPSS 23 (8th ed.). Semarang: Badan Penerbit Universitas Diponegoro. 
Gregorio, J. D. (2002). Education And Income Inequality: New Evidence From Cross-Country Data. Review of Income and Wealth, 48(3), 395-416.

Hassan, S. A., Zaman, K., \& Gul, S. (2015). The Relationship between Growth-InequalityPoverty Triangle and Environmental Degradation: Unveiling the Reality. Arab Economic and Business Journal, 10(1), 57-71.

Mankiw, N. G., Quah, E., \& Wilson, P. (2014). Pengantar Ekonomi Makro: Principles of Economics an Asian (2nd ed.). Jakarta: Salemba Empat.

Meisami, S. B. H. (2010). An Empirical Investigation of The Effects of Health and Education on Income Distribution and Poverty in Islamic Countries. International Journal of Social Economics, 37(4), 293 - 301.

Nachrowi, D. N., \& Usman, H. (2006). Ekonometrika untuk Analisis Ekonomi dan Keuangan. Jakarta: FE Universitas Indonesia.

Nielson, F., \& Alderson, A. S. (2015). The Kuznets Curve and The Great U-Turn: Income Inequality in U.S. Counties, 1970 To 1990. American Sociological Review, 62(1), 12-33.

Petcu, C. (2014). Does Educational Inequality Explain Income Inequality Across Countries? Retrieved from http://digitalcommons.iwu.edu/econ_honproj/125

Pi, J., \& Zhang, P. (2018). Structural Change And Wage Inequality. , 1-15. International Review of Economics and Finance, 58(C), 699-707. https://doi.org/10.1016/j.iref.2018.07.010

Rahardja, P., \& Manurung, M. (2008). Pengantar Ilmu Ekonomi (Mikroekonomi \& Makroekonomi) (3th ed.). Jakarta: FE Universitas Indonesia.

Sanz, R., Peris, J. A., \& Escámez, J. (2017). Higher Education in The Fight Against Poverty From The Capabilities Approach: The Case of Spain. Journal of Innovation \& Knowledge, 2(2), 53-66.

Shahpari, G., \& Davoudi, P. (2013). Studying Effects of Human Capital on Income Inequality in Iran. Procedia - Social and Behavioral Sciences, 109(2014), 1386-1389.

Sukirno, S. (2011). Makroekonomi Teori Pengantar. Jakarta: PT RajaGrafindo Persada.

Syawie, M. (2011). Kemiskinan dan Kesenjangan Sosial. Jurnal Informasi, 16(3), 213-219.

Syilviarani, A. T. (2017). Analisis Faktor Yang Mempengaruhi Ketimpangan Distribusi Pendapatan Di Pulau Jawa Tahun 2010-2015. Publikasi Ilmiah. Surakarta: Program Studi Ekonomi Pembangunan Fakultas Ekonomi dan Bisnis Universitas Muhammadiyah Surakarta.

Ukpere, W. I., \& Slabbert, A. D. (2009). A Relationship Between Current Globalisation, Unemployment, Inequality and Poverty. International Journal of Social Economics, $36(1-2), 37-46$.

Wahyuni, R. N. T., \& Monika, A. K. (2016). Pengaruh Pendidikan terhadap Ketimpangan Pendapatan Tenaga Kerja di Indonesia. Jurnal Kependudukan Indonesia, 11(1), 110-125.

Widarjono, A. (2007). Ekonometrika Teori dan Aplikasi Untuk Ekonomi dan Bisnis. Yogyakarta: Penerbit Ekonisia Fakultas Ekonomi UII. 
Wiratmini, N. P. E. (2018). Paling Rendah Di Indonesia, Pengangguran di Bali Hanya 36.000. Retrieved January 31, 2019, from https://kabar24.bisnis.com/read/20180124/78/730043/pali-renda-di-indonesiapengangguran-di-bali-hanya-36.000

Yang, J., \& Qiu, M. (2016). The Impact of Education on Income Inequality And Intergenerational Mobility. China Economic Review, 37(C), 110-125.

Yeimo, A. M. (2016). Pokok Permasalahan Pendidikan Masa Kini di Papua. Retrieved February 24, 2019, from https://suarapapua.com/2016/05/16/pokok-permasalahan-pendidikanmasa-kini-di-papua/ 